Journal Universitas Muhammadiyah Gresik Engineering, Social Science, and Health International Conference (UMGESHIC)

UMGCINMATIC : $1^{\text {st }}$ Rethinking Education during Covid-19 Era: Challange and Innovation

\title{
STUDY OF VARIABLES AFFECTING DIVIDEND POLICY IN MANUFACTURING COMPANIES ON THE INDONESIA STOCK EXCHANGE
}

\author{
Author \\ Anita Akhiruddin, SE, M.Sc ${ }^{1}$ \\ ${ }^{1}$ Management Study Program, Faculty of Economics and Business \\ Muhammadiyah University of Gresik \\ Jl. Sumatra No. 101, GKB Gresik Kota Baru (GKB) Gresik 61121, East Java, Indonesia \\ Email: anitariski2014@gmail.com
}

\begin{abstract}
Free cash flow (FCF), debt, and company growth are important factors in determining dividend policy. Dividends are very meaningful for shareholders to increase their wealth, on the other hand, dividends are a source of funds that can be used for investments that produce high returns. In addition, dividends are a positive signal for investors, if the company regularly distributes dividends, this results in a high share price of the company. The manager needs to consider a dividend strategy that can benefit the company's continuation in the future as well as stockholder confidence.

The sample of this research consists of the manufacturing industry on the Indonesia Stock Exchange and starting from 2016-2019 with a total of 32 samples. This research aims to prove the factors of free cash flow (FCF), debt and dividends and their effect on dividend policy by using multiple regression models.

The result of the research illustrates that there is a negative effect between free cash flow and dividend policy and this hypothesis is rejected because it is contrary to the hypothesis made. Meanwhile, dividend policy is influenced by debt policy and the result is significantly negative, and company growth has a negative and significant impact on debt policy.
\end{abstract}

Keywords: Dividend, FCF, Debt, Growth 


\section{INTRODUCTION}

Most investors in carrying out investment decisions have a goal, namely to get a profit on their investment, which can be seen from the rate of return, so as to increase the wealth owned by shareholders. (Azhagaiah and Priya; 2008). Investors hope that the distribution of dividends is always normal, meaning that dividends are distributed every period. If the distribution of dividends is given normally every period, then this can increase shareholder wealth and this becomes attractive for shareholders to make investment decisions. This is in accordance with the results of research by Aharony and Swary (1980) who found that dividend distribution information is a very valuable positive signal for shareholders compared to earnings announcement information.

Managers often use dividends to communicate information; one of which is related to the size of the company's income universally (Liu and Chen; 2015). The opposite; for companies that have poor performance, dividend distribution decisions are very difficult to make (Amihud and $\mathrm{Li}$ : 2002). Information related to dividend policy is a signaling theory in the form of negative information where the company does not make a dividend distribution policy.

Dividend payment policy is the authority of management (Papadakis; Liokas; and Chamber, 1998). If the company is considered to have great development, ultimately dividends will not be given to shareholders. Because managers prefer to hold some of the profits earned with the aim of expanding the business, paying debts or being kept as a reserve fund. This is different if the company is already in the stage of maturity and high profitability, so it prefers to distribute dividends (Month; Subramania; and Tanru; 2007). Meanwhile, shareholders or principals who will oversee the performance of management in running the company optimally and are able to generate profits for the company, so that shareholders can get dividends. Bandi (2009).

The important thing that management does before setting a dividend policy is to consider the sustainability of the company's life. Some of the profits obtained from the company are distributed in the form of dividends, and some are used for investments, paying debts and reserve funds. Companies that want to grow will take advantage of the profits that are not shared to invest so that the company continues to grow. The higher the growth rate of the company's assets, the less possibility the company will distribute dividends, because the funds originating from the free cash flow that are held are used to increase the company's assets (Endang and Minaya, 2003).

Free cash flow (FCF) is the remaining cash from the company's operational activities which is usually used for dividend payments, investments and company working capital which is often a problem between management and shareholders. Conflicts that occur are caused by differences in interests between managers and shareholders. Managers want to hold free cash 
flow so that it can be used if there is a promising investment for the company, while shareholders want free cash flow to be distributed in order to increase the amount of shareholder wealth. Free cash flow has an impact on dividend policy, this is in accordance with the research results of Atika Jauhari Hatta (2002).

In addition to free cash flow, dividend policy is also influenced by debt policy where companies finance using debt, the higher a company's debt will cause a decrease in the company's ability to pay dividends, this is because some of the company's profits are used to pay debts (Agus and Nurfauziah; (2006), with debt the company can control the use of free cash flow so that shareholders can receive dividends. If you look at this explanation, the author wants to see the influence of free cash flow, debt policy and the company's growth rate related to dividend policy.

\section{METHOD}

\subsection{Data source}

The data from this research comes from the Indonesia Stock Exchange which consists of manufacturing companies, and uses a purposive sampling method.

The criteria for the samples taken are:

1. Companies that pay dividends from $2016-2017$.

2. Companies that have complete data according to the needs of this research.

3. Companies that have differences in assets that are not too far apart to avoid extreme data. From the results of the selection of the criteria mentioned above, the companies that meet the criteria above are 8 companies with data collection for 4 years, so that a sample of 32 samples is obtained. The companies that are the sample are, PT. Gudang Garam Tbk, PT. Indocement Tunggal Prakarsa Tbk, PT. Mayora Indah Tbk, PT. JAPFA Comfeed Indonesia Tbk, PT. HM Sampoerna Tbk, PT. Kalbe Farna Tbk, PT. Charoen Pokphand Indonesia Tbk, : PT. Indofood Sukses Makmur Tbk.

\subsection{Research variable}

The dividend payout ratio is a comparison between the dividends distributed and the net income obtained, which is used to measure dividend policy (Sutrisno, 2003:304)

$$
P R=\frac{\text { Dividen per lembar saham }}{\text { laba bersih per lembar saham }}
$$




\section{Free Cash Flow}

According to Sutrisno (2013), free cash flow is the ratio between operating cash flow minus dividends and divided by total assets. If the profit earned by the company is used for funding, the free cash flow ratio will be smaller, so the dividends will also be smaller.

Free cash flow is calculated by the formula:

$$
\text { FCF }=\frac{\text { Arus kas operasi }- \text { Dividen }}{\text { Total Aktiva }}
$$

\section{Debt}

Debt in this research is measured by using the debt ratio. The debt ratio is used to measure the proportion of the company's funding.

$$
\text { Rasio Utang }=\frac{\text { Utang jangka panjang }}{\text { Total utang }+ \text { modal }}
$$

\section{Growth Rate}

Riyanto (2011, p.268) explained that "Company growth is the company's ability to enlarge the company's growth, so that the need for funds is also higher to finance the company's growth. The change in growth can be seen from the rise and fall of the company's total assets (Brigham \& Houston, 2015, p.372). The company's growth can be calculated from the total change in assets in the form of a percentage (Latiefasari, 2011).



\subsection{Data Analysis Techniques}

The tool used to test the hypothesis to be tested using multiple linear regression ( multiple regression ) can be said to be a good model if the model meets the BLUE (Best Linear Unbiased Estimator ) criteria, which needs to be tested for classical assumptions in the form of normality tests using statistical tests. non-parametric Kolmogrov-Smirnov test, multicollinearity test using the tolerance value and variance inflation factor (VIF), autocorrelation test using the DurbinWatson test, and lastly the heteroscedasticity test, namely whether there is an inequality of variance from the residuals (Ghozali, 2012:110)

\section{Multiple Linear Regression Test}


Linear regression is used to identify the effect of each independent variable on the dependent variable, or to calculate the size of the dependent variable from the known independent variables.

$$
\mathbf{Y}=\mathbf{b o}+\mathbf{b 1} \text { FCF }+ \text { b2 Utang }+ \text { b3 Growth }+\mathbf{e}
$$

\section{Where:}

$\mathrm{Y}=$ Dividend Policy

$\mathrm{FCF}=$ Free Cash Flow

Debt $=$ Debt Policy

Growth = company growth

\section{RESULTS AND DISCUSSION}

\subsection{Classical Assumption Test}

\section{Normality test}

A good model needs to do a normality test to see if the data is normally distributed or not. One way to test the normality of the residuals is the Kolmogrov-Smirnov non-parametric statistical test carried out by making a hypothesis (Ghozali, 2012:164).

Table 4.1

Kolmogorov Smirnov .test

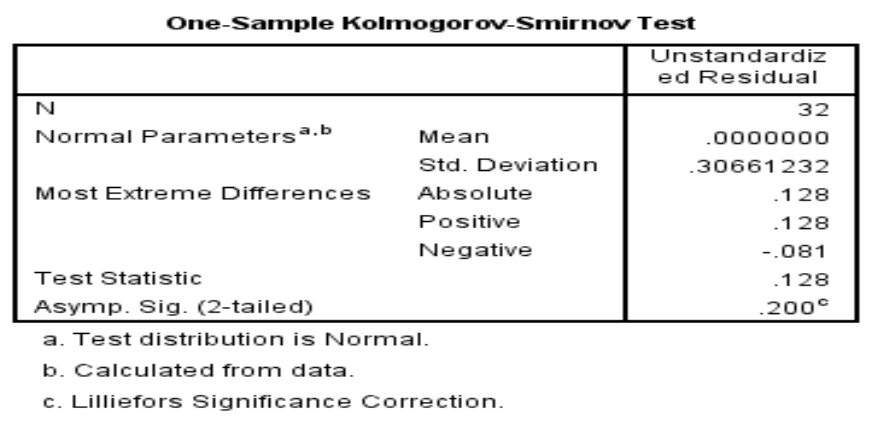

Source: SPSS output

Based on Figure 4.1 above, it shows that the Kolmogorov Smirnov test produces a significance of 0.200 , and is greater than $0.05(\alpha=5 \%)$, so it can be concluded that the residuals of the regression model are normally distributed. Thus the classical assumption of normality is met. 


\section{Multicollinearity Test}

The relationship between the independent variables in the equation can be tested by multicollinearity test. a good model requires that there is no strong relationship between the independent variables. A regression model is said to be multicollinearity free if the multicollinearity test results obtained VIF (Variance Inflation Factor) $<10$, and TOL $>0.10$ (Gujarati and Porter, 328; 2009). Table 4.2 shows that there are no symptoms of multicollinearity because the tolerance value is above 0.10 and the VIF value is below 10 .

Table 4.2

Multicollinearity Test

Coefficients ${ }^{\text {a }}$

\begin{tabular}{|l|r|r|}
\hline \multirow{2}{*}{ Model } & \multicolumn{2}{|c|}{ Collinearity Statistics } \\
\cline { 2 - 3 } & Tolerance & \multicolumn{1}{c|}{ VIF } \\
\hline FCF & .976 & 1.024 \\
Debt & .951 & 1.052 \\
Growth & .933 & 1.072 \\
\hline
\end{tabular}

Source: spss output

\section{Autocorrelation Test}

The correlation between error in period $t$ and error in period $t-1$ (previous) is known as autocorrelation test. If there is a correlation, it is said that there is an autocorrelation problem. To find out there is an autocorrelation using the Durbin-Watson test (Ghozali, 2012: 110).

Table 4.3

Autocorrelation Test

Model Summary ${ }^{\mathbf{b}}$

\begin{tabular}{|l|c|c|c|c|c|}
\hline Model & $\mathrm{R}$ & $\begin{array}{c}\mathrm{R} \\
\text { Square }\end{array}$ & $\begin{array}{c}\text { Adjusted } \\
\mathrm{R} \\
\text { Square }\end{array}$ & $\begin{array}{c}\text { Std. Error } \\
\text { of the } \\
\text { Estimate }\end{array}$ & $\begin{array}{c}\text { Durbin- } \\
\text { Watson }\end{array}$ \\
\hline 1 & $.823^{\mathrm{a}}$ & .738 & .695 & .322620 & 1.464 \\
\hline
\end{tabular}

a. Predictors: (Constant), Growth, FCF, Debt

b. Dependent Variable: Dividend

Source: SPSS output

Based on table 4.3, it is known that the Durbin Watson (DW) value is worth (4-d) $>\mathrm{dl}$ where the value is $(4-1.464)>1.2437$ so it can be concluded that there is no autocorrelation in the regression model.

\section{Heteroscedasticity Test}


Detect whether there is a heteroscedasticity problem with the glejser test. Where to see what the variance inequality occurs. If the significance probability value is above $5 \%$, it is estimated that there is no heteroscedasticity problem (Ghozali. 2012:139).

Table 4.4

Heteroscedasticity Test

Coefficients $^{\text {a }}$

\begin{tabular}{|c|c|c|c|c|c|c|c|c|}
\hline \multirow{2}{*}{\multicolumn{2}{|c|}{ Model }} & \multicolumn{2}{|c|}{$\begin{array}{l}\text { Unstandardized } \\
\text { Coefficients }\end{array}$} & \multirow{2}{*}{$\begin{array}{l}\text { Standardized } \\
\text { Coefficients } \\
\text { Beta }\end{array}$} & \multirow[b]{2}{*}{$\mathrm{T}$} & \multirow[b]{2}{*}{ Sig. } & \multicolumn{2}{|c|}{$\begin{array}{l}\text { Collinearity } \\
\text { Statistics }\end{array}$} \\
\hline & & B & Std. Error & & & & Tolerance & VIF \\
\hline \multirow[t]{4}{*}{1} & (Constant) & .405 & .064 & & 6.312 & .000 & & \\
\hline & FCF & -.209 & .656 & -.049 & -.318 & .753 & .976 & 1.024 \\
\hline & Debt & -.665 & .318 & -.327 & -2.091 & .066 & .951 & 1.052 \\
\hline & Growth & -1.203 & .459 & -.414 & $-2,621$ & .114 & .933 & 1.072 \\
\hline
\end{tabular}

a. Dependent Variable: Abresid

Source: SPSS Output

Based on table 4.4, it shows that the glejser test produces a significance value of t tolerance for each independent variable greater than 0.05 , meaning that there is no heteroscedasticity problem.

\section{Multiple Linear Regression Analysis}

Based on SPSS output display in table 4.3 models summary magnitude $\mathrm{R}^{2}$ is 0.738 means that $73.8 \%$ of the changes / variations in the value of the dividend variable (Y) can be explained by the variation of the independent variable (FCF, Debt and Growth), and the remaining 26.2\% is explained by other variables not included in this research.

Based on the ANOVA test table 4.5 or the F-test, the F-count is $11.144>$ F-table is 2.99, and the probability is below 0.05 so that $\mathrm{Ho}$ is rejected. This means that together (simultaneously) all independent variables (FCF, Debt, and Growth) have a significant and significant effect on dividends.

Table 4.5

Anova Test

\begin{tabular}{|ll|l|l|l|l|l|}
\hline Model & & Sum of Squares & $\mathrm{df}$ & Mean Square & $\mathrm{F}$ & Sig. \\
\hline 1 & Regression & 3.480 & 3 & 1,160 & 11.144 & $.000^{\mathrm{b}}$ \\
& Residual & 2,914 & 28 & .104 & & \\
& Total & 6.394 & 31 & & & \\
\hline
\end{tabular}

a. Dependent Variable: Dividend

b. Predictors: (Constant), Growth, FCF, Debt 
Source: SPSS output

Table 4.6

Multiple Linear Regression Test Results

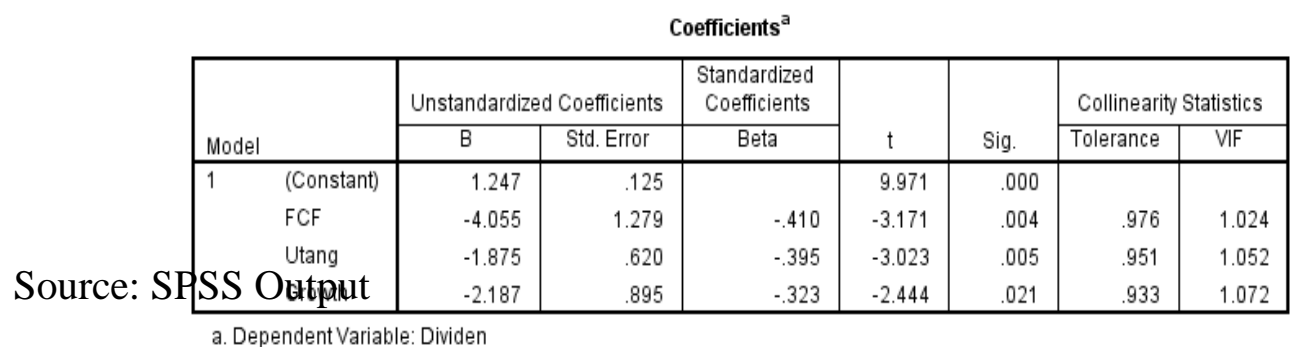

Based on table 4.6, it can be seen that all of the independent variables are significant below 005 . So we can make an equation as follows:

Dividend = 1,247 - 4,055 FCF - 1,875 Debt - 2,187 Growth

The regression results show that the constant value of 1.247 indicates that if the $F C F$, debt and growth variables are constant, the dividend policy will increase by 1.247 . Meanwhile, the coefficient of free cash flow, debt and growth has a negative effect on dividends and is significantly below $5 \%$.

\subsection{Hypothesis Testing and Discussion}

\section{Hypothesis 1}

The results of the regression test obtained that the free cash flow coefficient has a negative impact on dividend policy. This is different from hypothesis 1 where dividend policy is positively influenced by free cash flow (FCF) so that hypothesis one is rejected and is not in line with research expectations. A large free cash flow is expected to provide high dividends for shareholders and this is different from the results of this research. The reason is because high free cash flow is usually retained by managers to be invested in other projects which are expected to provide a large return for the company so that it can increase the company's growth on profits, as a result the distribution of dividends is lower.

\section{Hypothesis 2}

Hypothesis 2 explains that debt policy has a negative effect on dividend policy. From the regression analysis, the results show that debt has a negative effect on dividends and is significantly below 0.05 . The results of this research are in accordance with the results of research from Dithi (2013) who also found the same thing. So if the company's debt is higher, the dividends given are getting smaller, because some of the company's profits are allocated to pay off debt. 


\section{Hypothesis 3}

Hypothesis 3 states that asset growth has a negative and significant impact on dividend policy. This is evident from the regression results obtained. The more the company grows, the management will reduce the amount of dividends distributed, and this is in accordance with the research of Ross et al (2015.p.68) which is "companies that have high growth will tend to give low dividends, because the cash flow is used for investment financing, but if the company has reached a well stabilized session, the company will pay large dividends.

So it can be concluded that hypothesis 3 is accepted, thus it is evident that the higher the company's growth, the lower the proportion of dividends given, because some of the existing profits are used for investment in projects that are expected to provide even higher returns.

\section{CONCLUSION}

1. The free cash flow variable is not proven to have an effect on dividend policy so that hypothesis 1 is rejected because of investment opportunities, then free cash flow is used to finance the investment, so that the dividends given are getting smaller, while hypotheses 2 and 3 are accepted because they are theoretically proven.

2. An increase in the liquidity of a company is seen from the ability to pay its debts. As a result of paying debts with free cash flow, the dividends obtained by shareholders are small.

3. Debt policy is proven to be influenced by free cash flow, this is the same as the researchers' expectations. The tendency to use profits obtained by companies that have large growth is expected to increase the company's wealth in the form of investments that are expected to provide high returns, but that does not apply to companies that have reached maturity where investment opportunities are decreasing, so the profits tend to be distributed in the form of high dividends.

\section{Research Limitations}

The limitations of this research are:

1. The research period is only 4 years from $2016-2019$

2. The number of sample companies is only 32 companies because in 2019 many companies have not published their financial statements and many companies are not in a row in the distribution of dividends.

\section{SUGGESTION}


The researcher's suggestions for the next research are:

1. For further research, it is best to extend the research time to be used so that it can produce better research data

2. Future studies could use a larger number of companies who else is on the Stock Exchange.

3. Research variables can be added again, because there are many other factors that influence dividend policy, such as share ownership, company size.

4. The dividend variable used can use a dummy because of the limited company that distributes dividends so that more data can be obtained

\section{REFERENCES}

Agus Harjito and Nurfauziah. 2006." The Relationship of Debt Policy, Insider Ownership and Dividend Policy in Agency Problem Supervision Mechanisms in Indonesia”.. Jurnal Jaai Volume 10 No. 2, December 2006: 121 - 136. Yogyakarta: Faculty of Economics, Islamic University of Indonesia

Aharony, J. \& I. Swary. 1980. "Quarterly Dividend and Earnings Announcements and Stockholders Returns: An Empirical Analysis" The Journal of Finance .35(1), 1-12.

Atika Jauhari Hatta. 2002. " Factors Influencing Dividend Policy: Investigation of the Effect of Stock Holder Theory ". JAAI Volume 6 No.2. Yogyakarta: Faculty of Economics, Islamic University of Indonesia

Bandi.2009." Earnings Quality in the Perspective of Accrual-Cash Flow and Dividend Signaling”. Semarang: Doctoral Dissertation for Post-Graduate Program UNDIP.

Brigham and Houston. 2004." Financial Management, Book II". Jakarta: Erlangga.

Emery, Douglas R., John D. Finnerty and John D. Stowe. 2004. " Corporate Financial Management". Second Edition. United States. Pearson Education Inc.

Endang and Minaya. 2003. "Influence of Insider Ownership, Dispersion of Ownership, Free Cash Flow, Collaterizable Assets and Growth Rate on Dividend Policy". Yogyakarta” Journal of Economics and Business Volume 14. No. 21. August 2004, 281-301.

Evilia Nuri Rahmawati. 2009. " Analysis of the Effect of Shareholders' Dispersion, Dividend Payout Ratio, Firm Size, Asset Structure and Profitability on Debt Policy ". Surakarta: Indonesia. Thesis of the Faculty of Economics, University of Muhammadiyah Surakarta.

Hanafi M. Mamduh. 2004. Financial Management. Yogyakarta: BPFE

Hery, 2013. The Secret of Dividend Distribution \& Corporate Governance. Yogyakarta: Indonesia Gava Media 
Jencen, MC, and Fama, Eugene F. 1998. "Agency Problems and Residual Claims. Journal of Law \& Economics, Vol. XXVI. Foundations of Organizational Strategy Chapter 6”, Harvard University Press.

Jensen, MC, and Meckling, WH 2000. "Theory of the firm: managerial behavior, agency costs and ownership structure". Journal of Financial Economics 3: 305-360.

Jensen, MC, and Smith, Clifford W, Jr. 2000. "Stockholder, Manager, And Creditor Interests: Applications of Agency Theory" .Harvard University Press.

Liu; C. and AS Chen. (2015). "Do Firms Use Dividend Changes To Signal Future Profitability? A Simultaneous Equation Analysis ".International Review of Financial Analysis, 37, 194-207

Michelle Suherli. 2004." Empirical Study of Determinants of Dividend Amount Policy " Bandung: Media for Accounting, Auditing and Information Research . Journal Volume 4, No.3.

Papadakis, VM; S. Lioukas; and D. Chambers. 1998." Strategic Decision-Making Processes: The Role of Management and Context”. Strategic Management Journal: 19(2), 115147. 